\title{
РАНЖУВАННЯ ДІЯЛЬНОСТІ УНІВЕРСИТЕТІВ ЯК КЛЮЧОВИЙ ІНСТРУМЕНТ ПІДВИЩЕННЯ ЯКОСТІ МЕДИЧНОЇ ОСВІТИ
}

\author{
В. Ф. Москаленко, О. П. Яворовський, Л. І. Остапюк, А. І. Чубатий, В. С. Чешук \\ Національниймедичний університет імені О. О. Богомольияя
}

\section{RATING OF THE UNIVERSITIES' ACTIVITIES AS A KEY INSTRUMENT OF MEDICAL EDUCATION QUALITY IMPROVEMENT}

\author{
V. F. Moskalenko, O. P. Yavorovskyi, L. I. Ostapyuk, A. I. Chubatyi, V. Ye. Cheshuk \\ National Medical University by O. O. Bohomolets
}

\begin{abstract}
У статті проаналізовано показники міжнародних, національного рейтингів, галузевого рейтингу ВНЗ, ранжування факультетів, кафедр, студентів НМУ імені О. О. Богомольця, досліджено вплив рейтингів на підвищення якості освітнього процесу.
\end{abstract}

The article adduces the analysis of rating indices: of international, national; of the branch rating of higher educational establishments, ratings of the National O. O. Bohomolets Medical University faculties, departments, students; there is analysed influence of ratings on educational process quality improvement.

Вступ. Болонський процес, започаткований у 1999 році, постійно розвивається, свідченням цього є низка декларацій та комюніке, підписаних міністрами, які відповідають за вищу освіту в країнах Європи з 2001 до 2010 року.

У комюніке, яке було прийнято в Будапешті/Відні (2010р.), відмічають, що Європейський освітній простір до 2010 року сформований не повністю (його створення продовжено до 2020 року) та визначено ряд пріоритетів і завдань, основним серед яких є запровадження в освіті країн-учасниць Болонського процесу міжнародних стандартів і рекомендацій щодо забезпечення якості у Свропейському просторі вищої освіти.

Як зазначено у програмі економічних реформ України на 2010-2014 роки “Заможне суспільство, конкурентоспроможна економіка, ефективна держава" від 02.11.2010, ситуація у сфері освіти характеризується багатьма проблемами, головна 3 яких невідповідність якості освіти сучасним вимогам. Було відмічено, що Україна не представлена в жодному з основних міжнародних рейтингів найкращих університетів світу.

Вищезазначене свідчить про актуальність вивчення результатів міжнародних, вітчизняних, інституціональних рейтингів та їх впливу на якість освіти з метою подальшого іiі удосконалення.

Важко переоцінити важливість рейтингового оцінювання ВНЗ для абітурієнтів та їх батьків під час ви- бору місця навчання, для взаємного визнання навчальних програм університетів у СПВО, для орієнтації роботодавців при найманні на роботу випускників університетів. Саме тому виникає проблема моніторингу якості вищої освіти як системи постійного спостереження та контролю за процесами, що відбуваються у вищій освіті на різних рівнях [2].

Незважаючи на дискусійність застосовуваних критеріїв у найавторитетніших міжнародних рейтингах, саме вони $є$ ключовим інструментом оцінки якості освіти, двигуном реформ і спрямовані на поліпшення стандартів та рівня освіти на інтеграцію до ЄПВО.

Основна частина. У Шанхайському рейтингу (ТОП-500) - Academic Ranking of World Universities (Shanghai Jiao Tong University) та рейтингу “Таймс" (ТОП-400)-the Times Higher Education (THE) World University Rankings, як найавторитетніших міжнародних рейтингах, не представлено у 2011 році українські вищі навчальні заклади. У рейтингу (ТОП-700) QS World University Rankings серед переможців є 2 університети України: 611 місце - Донецький національний університет і 630 місце - Національний технічний університет України (КПI). Щодо кращих університетів світу в галузі знань "Медицина" у Шанхайському рейтингу (ТОП-500) в першій десятці 7 університетів США і 2 університети Великої Британії та жодного університету з країн СНД та України. Вважаємо правомірним навести цитату: “....домі-

( В. Ф. Москаленко, О. П. Яворовський, Л. І. Остапюк та ін. 
нування університетів США і Великої Британії у міжнародних рейтингах стали підставою для переходу на багаторівневу організацію системи освіти в межах Європейського простору вищої освіти i, зокрема, на ступеневу освіту в Україні” [3].

Як шлях підвищення професіоналізму у вищій освіті, розглядають участь ВНЗ України в рейтингу ЮНЕС КО “ТОП-200 Україна”, який відмічає в цьому році 5-річний ювілей. Саме цей рейтинг трансформує до умов України ідеї таких міжнародних рейтингів, як “Всесвітній рейтинг Шанхайського університету Цзяо Тун”, "Всесвітнього рейтингу університетів", який публікують у газеті “Таймс", США та інших. В рейтингу "ТОП-200 Україна" діяльність ВНЗ оцінюють за допомогою інтегрованого Із - індексу, який включає три комплексні складові: Із=Інп+ІІн+Імв, де Інп - індекс якості науковопедагогічного потенціалу, Ін - індекс якості навчання, Імв - індекс міжнародного визнання. Методику проведення рейтингу “ТОП-200 Україна” створено відповідно до Берлінських принципів ранжування університетів (2006 р.). Як відмічають організатори рейтингу “ТОП-200 Україна”, його слабкою ланкою, як й інших рейтингових систем України, $є$ низька достовірність даних, які надають ВНЗ. Це пов'язано 3 недосконалим інформаційним простором у царині освіти нашої держави (відсутність точної об'єктивної інформації на сайтах університетів та інших освітніх організацій).

Серед 200 університетів України учасниками рейтингу “ТОП-200 Україна” у 2011 році є 13 ВМ(Ф)НЗ, які зайняли відповідні місця в першій сотні. Національний медичний університет імені О. О. Богомольця отримав почесне 4 місце серед 200 ВНЗ, але поступається за індексом оцінки якості навчання До- нецькому національному медичному університету імені М. Горького та Національному фармацевтичному університету, а також Українській медичній стоматологічній академії за індексом міжнародного визнання [www.zn.ua].

Важливим інструментом підвищення якості та конкурентоспроможності вищої освіти в Україні є Національна система рейтингового оцінювання діяльності ВН3, яку створено Міністерством освіти і науки, молоді та спорту України з врахуванням досвіду міжнародних рейтингових агентств на реалізацію розпорядження Кабінету Міністрів України від 01.04.2004 p., № 208-р "Про схвалення Концепції створення системи рейтингової оцінки регіонів, галузей національної економіки, суб'єктів господарювання". Зазначений рейтинг вже восьмий рік поспіль проводить ранжування вищих навчальних закладів III-IV рівнів акредитації.

Положення про національну систему рейтингового оцінювання діяльності вищих навчальних закладів, затверджене наказом Міністерства освіти і науки, молоді та спорту України від 20.12.2011 р., № 1475, визначає суб'єктами ранжування вищі навчальні заклади III-IV рівнів акредитації за типами: університети, академії, консерваторії, інститути та зобов'язує керівників вищих навчальних закладів забезпечити подання даних до Єдиної державної електронної бази 3 питань освіти для проведення рейтингового оцінювання діяльності ВН3 щорічно [4].

Стратегічною метою моніторингу є забезпечення громадськості достовірною, об'єктивною та точною інформацією про якість освітньої діяльності та вищої освіти, що надають ВНЗ України.

При цьому вищі навчальні заклади України ранжуються за індексами тематичних напрямків та глобального критерію рейтингу:

\begin{tabular}{|c|c|}
\hline Умовне позначення індексу $\left(\mathrm{I}_{\mathrm{t}}\right)$ & Назва індексу $\left(\mathrm{I}_{\mathrm{t}}\right)$ тематичного напрямку (профілю) \\
\hline $\mathrm{I}_{1}$ & Індекс міжнародної активності \\
\hline $\mathrm{I}_{2}$ & Індекс національного визнання \\
\hline $\mathrm{I}_{3}$ & Індекс доступу, масштабів, результативності \\
\hline $\mathrm{I}_{4}$ & Індекс якості науково-педагогічного персоналу \\
\hline $\mathrm{I}_{5}$ & Індекс підготовки наукових та науково-педагогічних кадрів \\
\hline $\mathrm{I}_{6}$ & Індекс інтеграції науки, творчості та вищої освіти \\
\hline $\mathrm{I}_{7}$ & Індекс ресурсного забезпечення навчального процесу \\
\hline $\mathrm{I}_{8}$ & Індекс наукометричної бази даних Scopus \\
\hline $\mathrm{IPI}$ & Інтегральний рейтинговий індекс (IPI $\left.=\Sigma \mathrm{I}_{\mathrm{t}}\right)$ \\
\hline
\end{tabular}

Серед ВН3, що ранжуються таким чином, наявні класичні, профільні університети та академії, в тому числі медичні.

Результати аналізу рейтингового оцінювання діяльності ВНЗ України у 2009-2010 н.р. та 2010 календарному році свідчать, що 15 вищих медичних на- вчальних закладів України були суб' єктами ранжування. Відповідно до структури розподілу позиціонування цих закладів на рейтингових шкалах індексів тематичних напрямів, за інтегральним рейтинговим індексом НМУ зайняв перше місце серед ВМНЗ України. Разом з тим, є ряд тематичних показників, 
які хотілося б поліпшити у нашому університеті, оскільки вони є нижчими за показники інших університетів. Так, наприклад, за профілем “Доступ, масштаби, результативність" Вінницький національний медичний університет імені М. І. Пирогова, Луганський державний медичний університет, Тернопільський державний медичний університет імені I. Я. Горбачевського та Одеський національний медичний університет мають вищий показник індексу тематичного напрямку (профілю) на відміну від Національного медичного університету імені О. О. Богомольця, який посідає лише сьому позицію.

За напрямком "Ресурсне забезпечення" (соціальна підтримка, фінансові та інформаційні ресурси) першість утримують Луганський державний медичний університет, Запорізький державний медичний університет і Національний фармацевтичний університет.

Донецький національний медичний університет імені Максима Горького, Одеський національний медичний університет, Національний фармацевтичний університет, Буковинський державний медичний університет займають перші місця за напрямком "Наукометрична база даних Scopus".

Наведений аналіз ранжування свідчить про необхідність пошуку шляхів підвищення пріоритетних показників діяльності університету, а отже, підвищення якості освітньо-виховного процесу.

Галузевий моніторинг якості у вищій школі здійснюють через національні інтегровані тестові іспити, які в різному статусі успішно реалізує Центр тестування МОЗ України з 1998 року. Ця система моніторингу пройшла міжнародну експертизу, успішно розвивається та активно презентується на міжнародних конференціях; щорічні результати ліцензійних інтегрованих іспитів “Крок-1” і “Крок-2" є важливим інструментом своєрідного аудиту освітньої діяльності кожного ВМ $(\Phi) Н 3$ України, а також важливим для визначення його місця в галузі.

В Національному медичному університеті імені О. О. Богомольця впродовж останніх семи років успішно використовують внутрішньоуніверситетський рейтинг, який дозволяє щорічно визначати кращі ка-

\section{Література}

1. Будапештсько-Віденська декларація про створення Європейського простору вищої освіти. -12 березня 2010 p.

2. Ямковий В. Ранжування університетів - крок до відкритості та прозорості вищої освіти / В. Ямковий // Вища школа. -2007. -№3.-С. 31 .

3. Сухарніков Ю. Концептуальні підстави розробки і впро- федри і факультети за результатами навчально-методичної, наукової, виховної, лікувально-діагностичної та профілактичної роботи, кадрового забезпечення, міжнародного та галузевого визнання. "Показники рейтингової оцінки діяльності кафедр і факультетів НМУ" постійно оновлюються відповідно до чинних показників національної системи рейтингового оцінювання діяльності ВНЗ. Проведення внутрішньовузівського ранжування дозволило домогтися від факультетів та кафедр більш ефективної роботи за всіма напрямками діяльності.

Моніторинг роботи студентів Національного медичного університету імені О. О. Богомольця впродовж останніх років визначають за "Рейтинговою системою оцінювання діяльності студентів", що включає три основні компоненти: оцінку результатів навчання, результативність участі у науковій роботі, а також участь в студентському самоврядуванні, громадській та спортивно-масовій роботі, в художній самодіяльності тощо. Передбачені також штрафні бали, які відраховують від загальнорічної кількості балів. Щорічно переможців рейтингу нагороджують цінними подарунками; студентам контрактної форми навчання, як винагороду, зменшують вартість навчання.

Висновок. Участь університетів у рейтингах різних рівнів, моніторинг їх діяльності, що передує рейтингу, дає змогу виявити слабкі сторони, проблемні питання, проаналізувати їх причини і на основі цього сформувати стратегічні напрямки для поліпшення освітньо-виховного процесу.

Участь університетів у національному рейтингу, в рейтингу ЮНЕСКО “ТОП-200 Україна” за інтегральними рейтинговими індексами сприяє використанню синергетичного системного підходу до створення сучасної системи менеджменту якості.

Важливим для підвищення міжнародного авторитету держави та галузі $є$ проведення внутрішнього та зовнішнього аудиту діяльності ВМ $(\Phi)$ НЗ України на основі принципів та вимог Свропейських стандартів та директив 3 гарантії якості (ENQA) та всесвітніх стандартів медичної освіти, розроблених Світовою федерацією медичної освіти (WFME).

вадження національної рамки (академічних) кваліфікацій України / Ю. Сухарніков// Вища школа.-2012.-№3.-С. 17.

4. Про затвердження Положення про національну систему рейтингового оцінювання діяльності вищих навчальних закладів : наказ Міністерства освіти і науки, молоді та спорту України № 1475 від 20.12.2011p. 